\title{
Propensity for seed-mediated gene flow from potato crops and potential consequences for the coexistence of GM and non-GM potato systems
}

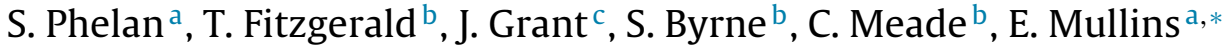 \\ a Department of Crop Science, Crops Environment and Land Use Programme, Teagasc Oak Park, Carlow, Ireland \\ ${ }^{\mathrm{b}}$ Department of Biology, National University of Ireland Maynooth, Maynooth, Ireland \\ c Teagasc Statistics and Applied Physics, Research Operations Group, Ashtown, Dublin 15, Ireland
}

\section{A R T I C L E I N F O}

\section{Article history:}

Received 1 October 2013

Received in revised form 5 March 2015

Accepted 18 March 2015

Available online 9 April 2015

\section{Keywords:}

Potato

Coexistence

GM

Ireland

Volunteers

\begin{abstract}
A B S T R A C T
Potato is a critical crop to European growers, both economically and agronomically as a break crop in the standard cereal rotation. As studies investigating the agronomic performance and environmental impact of disease resistant, GM potatoes come to an end across several sites in Europe, past discussions on achieving the effective coexistence of GM and equivalent non-GM crops have too often focussed on the purported risk of excessive pollen-mediated gene flow. Dependent on the crop in question, the impact of seed loss pre- and/or post-harvest presents a greater challenge to securing efficient coexistence practises. To examine this issue for potato, a total of 51 fields that had been commercially cultivated with potatoes were surveyed in two separate cohorts for post-harvest tuber loss and/or volunteer emergence. Across 17 fields studied, the average post-harvest tuber loss was recorded at 141,758 \pm 911 tubers $^{-1}$, with volunteer establishment in the following crop ranging from $400 \pm 59 \mathrm{ha}^{-1}$ to $55,698 \pm 47 \mathrm{ha}^{-1}$. In parallel, by surveying a separate cohort of 34 commercial fields an average of $30,789 \pm 2658$ volunteer $\mathrm{ha}^{-1}$ was recorded in the subsequent cereal crop, with a repeat survey made after an additional year indicating an $87.2 \%$ reduction in this mean number of volunteers across the 34 fields $(P<0.001)$. Of the additional variables studied only location $(P<0.001)$, herbicide application $(P=0.037)$ and potato variety used $(P=0.045)$ significantly influenced volunteer proliferation. Volunteer fecundity was confirmed with upto 3 tubers produced per 1 st generation volunteer, with tuber yield from the 2 nd generation volunteers reduced significantly $(P<0.001)$. Assessments of the tuber lots from these 2 nd generation volunteers confirmed their ability to sprout post-dormancy, therefore, indicating the potential for 3rd generation volunteers to emerge. Combined, the datasets confirm the potential for significant seed-mediated gene flow from commercial potato systems; indicating that the regulated $0.9 \%$ coexistence threshold would in all probability be compromised if GM potatoes were grown in rotations of 1:4 years or less, in the absence of a comprehensive tuber loss and/or volunteer management system.
\end{abstract}

(c) 2015 Elsevier B.V. All rights reserved.

\section{Introduction}

Potato is the fourth largest food crop in the world and the second most important arable crop in Europe, with up to 6 million hectares (ha) grown at a value close to $€ 6$ billion per annum (Haverkort et al., 2008). For Ireland, the potato remains the most important field grown horticultural crop ( $\sim 10,000$ ha per annum) supporting an industry with an annual net worth approaching $€ 200$ million. As is the case in nearly all potato growing regions of the world,

\footnotetext{
* Corresponding author. Tel.: +353 59 9170298; fax: +353 599142423.

E-mail address: ewen.mullins@teagasc.ie (E. Mullins).
}

the most significant challenge to potato yields remains late blight disease, caused by the oomycete pathogen Phytophthora infestans. Annual losses (costs of control and damage) in Europe are estimated at more than $€ 1$ billion, with growers typically having to employ intensive spray regimes to exert adequate control to protect their crop returns (Haverkort et al., 2008). While the mild climate encourages high yields in Ireland the same climate also supports high disease pressure in the national potato crop (Dowley et al., 2008 ) with potato growers typically applying up to 15 fungicide applications per crop.

Undeniably, the deployment of durable resistant varieties is the most sustainable strategy to tackle late blight disease (McDonald and Linde, 2002) but the resilience of some previously deployed 
late blight resistance genes (R genes) has been disappointing (Fry, 2008). In addition, the issue is complicated by the period ( $\sim 15$ years) that is required to breed a variety through conventional breeding techniques. Whereas genetic tools such as marker assisted selection can decrease the breeding time somewhat, GM technologies can overcome inter-specific hybridisation barriers (Song et al., 2003; Van Der Vossen et al., 2003) and significantly decrease the breeding period. As multiple $\mathrm{R}$ genes have been described in the literature from a range of wild potato species and their interaction with P. infestans characterised (Vleeshouwers et al., 2011); the ability to functionally stack up to three R genes in the same variety (Zhu et al., 2012) further underlines the ability of GM techniques (be that transgenic or cisgenic) to generate disease resistant germplasm.

Field-based evaluations of late blight resistant GM potatoes have recenty been completed through such initiatives as the DuRPh programme in the Netherlands (Haverkort et al., 2009) and separately in the UK (Jones et al., 2014), with both studies demonstrating the efficacy of the selected R genes to any future commercial breeding programmes. However, from a European context any future plan to commercialise GM potatoes highlights the necessity to develop adequate coexistence measures; in order to ensure the effective segregation of neighbouring GM and non-GM potato crops. The issue is all the more relevant in light of new EU policies that nationalise the decision making process on GM crop cultivations. If implemented, scenarios are likely to arise where neighbouring states adopt opposite views on the cultivation of individual GM crops; thereby underlining the importance of coexistence measures across their respective border regions.

Coexistence relates to the adoption of crop-specific management regimes to maintain the adventitious presence of authorised transgenes in conventional/organic commodities below the $0.9 \%$ labelling threshold for food or feed (E. Commission, 2003). In short, coexistence is focused on restricting the potential for and consequence of a GM crop's gene flow, whether via seed and/or pollen; thereby preserving the genetic integrity of related organic and/or conventional crops cultivated nearby. The impact of not establishing appropriate identity preservation systems for GM potato has already been highlighted, as seen with the failure of GM potatoes in North America in the 1990s (Toevs et al., 2011). Owing to its clonal propagation and its low pollen transmission distances, the potential for pollen-mediated gene flow from potato production systems to challenge the $0.9 \%$ threshold in adjacent crops is negligible (Petti et al., 2007). In contrast, the potential for tuber- and/or seed-mediated gene flow from potato crops is predicted to be significant (Flannery et al., 2005), but the consequence of such gene flow has yet to be determined.

Post-harvest tuber loss presents a significant weed problem with the proliferation of potato volunteers in follow on crops a common occurrence in regions with moderate winter temperatures. The problem has been documented for considerable time (Lutman, 1977; Lumkes, 1974) with more recent reports detailing the potential of potato volunteers to harbour bacterial and viral diseases (Perminow et al., 2012; van Elsas et al., 2000; Wright and Bishop, 1981) and act as primary sources of late blight inoculum (Cooke et al., 2011). Managing volunteer potatoes remains a challenge though in follow on crops (Boydston and Williams, 2005; Williams and Boydston, 2006); because of the energy reserves present in the volunteer's tubers (Williams and Boydston, 2002) and their ability to withstand control measures (Koepke-Hill et al., 2010).

National guidelines in Ireland recommend a 1 in 4 year rotation for potato cultivation, with the potato crop usually followed by a cereal rotation. However, this is not mandated for and cases often arise where potatoes are grown more frequently in a cereal rotation. In the Netherlands, this is also the case with potatoes cultivated for starch production often included in a 1 in 2 year rotation. In Ireland, the potato crop is typically harvested from September to November but in recent years above average rainfall from atypical weather patterns has made it difficult for growers to complete the harvest, as experienced from 2009 to 2011. The impact of such harvest disruption on the potential for volunteer emergence is as yet unknown; as indeed is the potential impact on coexistence measures should a GM potato market develop in the future.

Taking this into consideration the aim of this research was to begin to address the existing knowledge deficit by quantifying the level of post-harvest tuber loss across Irish commercial potato systems. The degree of volunteer emergence (and their resulting fecundity) in rotational crops and the impact of management practises on volunteer occurrence was also determined. Further to this we made an attempt to estimate the potential impact of high postharvest tuber loss and inadequate volunteer management on any future strategy for the effective coexistence of GM and non-GM potato systems.

\section{Materials and methods}

Two independent surveys of commercial potato farms were completed for this study. The first was conducted on 34 fields across the mid-eastern county of Meath, the eastern counties of Louth and Dublin, the south eastern county of Wexford and the southern county of Cork. The goal of this survey was to quantify the number of volunteers in the first (2010) and second (2011) year after potato cultivation; hence first and second generation potato volunteers in the summer of 2010 and 2011, respectively. While it was assumed that second generation volunteers were derived from first generation tubers, the possibility that a percentage of the second generation volunteers may have originated from residual tubers of the original potato crop could not be discounted.

Based on the initial results returned from the volunteer assessments in 2010, a second, separate survey was initiated in the autumn of 2010 across 17 separate potato fields based in the southeastern county of Wexford and the eastern county of Dublin with the intention of recording post-harvest tuber loss and the follow on emergence of volunteers (1st generation) in the summer of 2011. The management history (34 field survey in Table $1 ; 17$ field survey in Table 2) of all fields surveyed was recorded from grower's responses to a pre-survey questionnaire. The study had no influence over the varieties sown or the associated management regimes adopted by growers across the fields of the survey and the selected sites were located in those counties that are included in the primary potato producing regions of the country.

\subsection{Field management regimes}

For all the fields in the study, only 5 varieties (British Queen, Kerr's Pink, Records, Maris Piper and Rooster) were sown (to standard depth of $17 \mathrm{~cm}$ ) and prior to planting the potato crop, potatoes had not been sown in any of the surveyed fields for at least 5 years previous. Although the study had no control over the cropping regimes of the fields, responses collated from the questionnaire confirmed the relative uniformity of management practises across the participating commercial growers (Tables 1 and 2).

While the typical harvesting period is June-November, the inclement weather through the autumn and winter of 2009 led to the partial harvesting of three fields: F28 (October 2009), F29 (October 2009) and F37 where attempts to harvest were delayed until February/March 2010. Of the total 51 fields surveyed across the study, the potato crops in two fields (F18 and F24) were not harvested due to extremely poor soil conditions; hence, the crops in both sites were ploughed under the following spring. In addition, the harvesting of 5 fields (F21, F22, F23, F36 and F37) was postponed by growers until the following spring to minimise the impact of 
Table 1

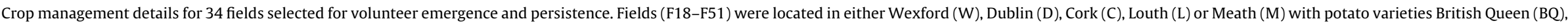

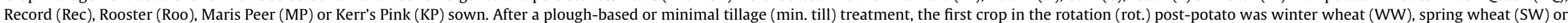

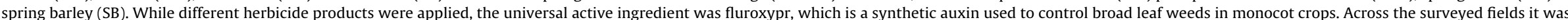
applied at rates ranging from $0 \mathrm{~g}, 50 \mathrm{~g}, 140 \mathrm{~g}, 172 \mathrm{~g}$ up to $216 \mathrm{~g} \mathrm{ha}^{-1}$.

\begin{tabular}{|c|c|c|c|c|c|c|c|c|c|c|c|c|}
\hline Field Code & Potato var. & Harvest date & Tillage type & Date of tillage & 1st rot. crop & Date of sowing & Herbicide a.i. applied & Harvest date & 2nd rot. crop & Date of sowing & Herbicide a.i. applied & Harvest date \\
\hline $\mathrm{F} 18-\mathrm{C}$ & Roo & & Plough & February10 & SB & February 10 & $140 \mathrm{~g}$ & August 10 & WW & October 10 & $140 \mathrm{~g}$ & July 11 \\
\hline F19-C & КР & September 09 & Plough & February 10 & SW & February 10 & $140 \mathrm{~g}$ & August 10 & Maize & April 11 & $140 \mathrm{~g}$ & October 11 \\
\hline $\mathrm{F} 20-\mathrm{C}$ & КР & September 09 & Plough & February 10 & SB & February 10 & $140 \mathrm{~g}$ & August 10 & WW & October 10 & $140 \mathrm{~g}$ & July 11 \\
\hline F21-D & Roo & April 10 & Plough & April 10 & SB & April 10 & $0 \mathrm{~g}$ & August 10 & Parsnip & April 11 & $0 \mathrm{~g}$ & November 11 \\
\hline F22-D & Roo & April 10 & Plough & April 10 & SB & April 10 & $0 \mathrm{~g}$ & August 10 & Parsnip & April 11 & $0 \mathrm{~g}$ & November 11 \\
\hline F23-D & Roo & April 10 & Plough & April 10 & SB & April 10 & $0 \mathrm{~g}$ & August 10 & Parsnip & April 11 & $0 \mathrm{~g}$ & November 11 \\
\hline F24-D & Roo & & Plough & April 10 & SB & April 10 & $50 \mathrm{~g}$ & August 10 & wW & October 10 & $50 \mathrm{~g}$ & July 11 \\
\hline F25-D & Roo & October 09 & Plough & January 10 & SW & February 10 & $216 g+{ }^{\dagger} 60 g$ & August 10 & Onions & March 11 & $216 \mathrm{~g}$ & September 11 \\
\hline F26-D & Roo & October 09 & Plough & April 10 & SB & April 10 & $216 \mathrm{~g}$ & August 10 & SW & February 11 & $216 \mathrm{~g}$ & August 11 \\
\hline F27-D & Roo & October 09 & Plough & April 10 & SB & April 10 & $216 \mathrm{~g}$ & August 10 & WW & October 10 & $216 \mathrm{~g}$ & August 11 \\
\hline F28-D & Roo & October $09^{\mathrm{a}}$ & Plough & February 10 & SW & February 10 & $140 \mathrm{~g}$ & August 10 & SB & April 11 & $140 \mathrm{~g}$ & August 11 \\
\hline F29-D & КР & October $09^{\mathrm{a}}$ & Plough & February 10 & SB & February 10 & $50 \mathrm{~g}$ & August 10 & WW & October 10 & $50 \mathrm{~g}$ & August 11 \\
\hline F30-D & KP & October 09 & Plough & April 10 & SB & April 10 & $50 \mathrm{~g}$ & August 10 & WW & October 10 & $50 \mathrm{~g}$ & August 11 \\
\hline F31-D & KР & October 09 & Plough & April 10 & SB & April 10 & $216 \mathrm{~g}$ & August 10 & WW & October 10 & $50 \mathrm{~g}$ & August 11 \\
\hline F32-D & MP & October 09 & Plough & April 10 & SB & April 10 & $50 \mathrm{~g}$ & August 10 & WW & October 10 & $216 \mathrm{~g}$ & August 11 \\
\hline F33-D & MP & October 09 & Plough & April 10 & SB & April 10 & $216 \mathrm{~g}$ & August 10 & sW & February 11 & $216 \mathrm{~g}$ & August 11 \\
\hline F34-D & MP & October 09 & Plough & March 10 & SB & March 10 & $216 \mathrm{~g}$ & August 10 & WW & October 10 & $216 \mathrm{~g}$ & August 11 \\
\hline F35-M & Roo & September 09 & Min till & March 10 & SW & April 10 & $140 \mathrm{~g}+45 \mathrm{~g}$ & August 10 & WW & October 10 & $140 \mathrm{~g}+45 \mathrm{~g}$ & August 11 \\
\hline F36-M & Roo & March 10 & Plough & March 10 & SW & April 10 & $140 \mathrm{~g}+45 \mathrm{~g}$ & August 10 & WW & October 10 & $140 \mathrm{~g}+45 \mathrm{~g}$ & August 11 \\
\hline F37-M & Roo & March $10^{\mathrm{a}}$ & Plough & March 10 & SW & April 10 & $140 \mathrm{~g}+45 \mathrm{~g}$ & August 10 & wW & October 10 & $140 \mathrm{~g}+45 \mathrm{~g}$ & August 11 \\
\hline F38-M & Roo & September 09 & Plough & September 09 & SB & February 10 & $216 \mathrm{~g}$ & August 10 & WW & October 10 & $140 \mathrm{~g}$ & August 11 \\
\hline F39-W & Roo & June 09 & Plough & April 10 & SB & April 10 & $216 \mathrm{~g}$ & August 10 & WW & October 10 & $216 \mathrm{~g}$ & August 11 \\
\hline F40-W & Roo & July 09 & Plough & March 10 & SW & March 10 & $216 \mathrm{~g}$ & August 10 & WW & October 10 & $216 \mathrm{~g}$ & August 11 \\
\hline F41-W & Roo & June 09 & Plough & March 10 & so & March 10 & $216 \mathrm{~g}$ & August 10 & WW & October 10 & $216 \mathrm{~g}$ & August 11 \\
\hline F42-W & Roo & June 09 & Plough & November 09 & WW & November 09 & $216 \mathrm{~g}$ & August 10 & WW & October 10 & $216 \mathrm{~g}$ & August 11 \\
\hline F43-W & Roo & June 09 & Plough & March 10 & so & March 10 & $216 \mathrm{~g}$ & August 10 & WW & October 10 & $216 \mathrm{~g}$ & August 11 \\
\hline F44-W & KP & June 09 & Plough & April 10 & SB & April 10 & $0 \mathrm{~g}$ & August 10 & WW & October 10 & $0 \mathrm{~g}$ & August 11 \\
\hline F45-W & KP & June 09 & Plough & March 10 & SW & March 10 & $216 \mathrm{~g}$ & August 10 & WW & October 10 & $216 \mathrm{~g}$ & August 11 \\
\hline F46-W & MP & September 09 & Plough & April 10 & SB & April 10 & $0 \mathrm{~g}^{\mathrm{a}}$ & August 10 & WW & October 10 & $0 \mathrm{~g}$ & August 11 \\
\hline F47-W & MP & September 09 & Plough & April 10 & SB & April 10 & $0 \mathrm{~g}^{\mathrm{a}}$ & August 10 & WW & October 10 & $0 \mathrm{~g}^{\mathrm{b}}$ & August 11 \\
\hline F48-L & Roo & November 09 & Plough & November 09 & WW & November 09 & $172 \mathrm{~g}$ & August 10 & WW & October 10 & $172 \mathrm{~g}$ & August 11 \\
\hline F49-L & Roo & November 09 & Plough & November 09 & WW & November 09 & $172 \mathrm{~g}$ & August 10 & wW & October 10 & $172 \mathrm{~g}$ & August 11 \\
\hline F50-L & Roo & November 09 & Plough & March 10 & sW & March 10 & $172 \mathrm{~g}$ & August 10 & WW & October 10 & $172 \mathrm{~g}$ & August 11 \\
\hline F51-L & Roo & October 09 & Plough & March 10 & SW & March 10 & $172 \mathrm{~g}$ & August 10 & WW & October 10 & $172 \mathrm{~g}$ & August 11 \\
\hline
\end{tabular}

a Potato harvesting was completed on the respective dates with the exception of fields where harvesting was partially completed.

b Sprout suppressant applied before harvesting tubers from potato crop.

${ }^{\dagger}$ For F25-D (2010), F35-M, F36-M and F37-M an additional mixture containing thifensulfuron methyl + tribenuron methyl was also applied at designated rates per hectare. 
Table 2

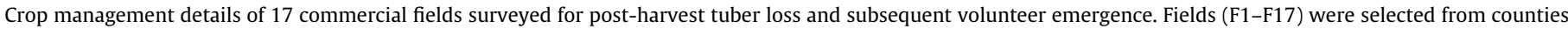

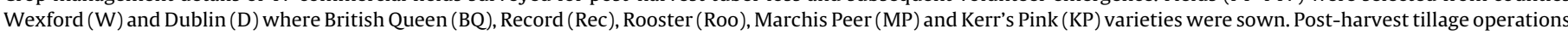

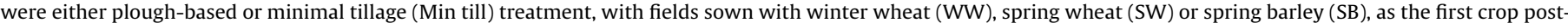

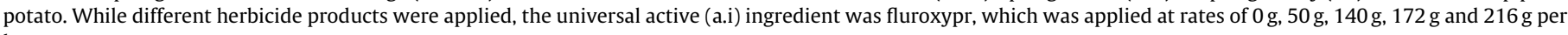
hectare.

\begin{tabular}{|c|c|c|c|c|c|c|c|c|}
\hline Field Code & Potato variety & Harvest date & Tillage type & Date of tillage & 1st rotation crop & Date of sowing & Herbicide a.i applied & Date of harvest \\
\hline F1-W & Roo & July 10 & Plough & October 10 & WW & October 10 & $216 \mathrm{~g}$ & August 11 \\
\hline F2-W & Roo & July 10 & Plough & October 10 & WW & October 10 & $216 \mathrm{~g}$ & August 11 \\
\hline F3-W & $\mathrm{KP}$ & July 10 & Plough & February 11 & SW & February 11 & $216 \mathrm{~g}$ & August 11 \\
\hline F4-W & KP & July 10 & Plough & February 11 & SW & February 11 & $216 \mathrm{~g}$ & August 11 \\
\hline F5-W & MP & July 10 & Plough & February 11 & SB & February 11 & $216 \mathrm{~g}$ & August 11 \\
\hline F6-W & MP & July 10 & Plough & February 11 & SB & February 11 & $216 \mathrm{~g}$ & August 11 \\
\hline F7-W & $\mathrm{BQ}$ & July 10 & Plough & October 10 & WW & October 10 & $216 \mathrm{~g}$ & August 11 \\
\hline F8-W & $\mathrm{BQ}$ & August 10 & Plough & October 10 & WW & October 10 & $216 \mathrm{~g}$ & August 11 \\
\hline F9-W & $\mathrm{BQ}$ & August 10 & Plough & October 10 & WW & October 10 & $216 \mathrm{~g}$ & August 11 \\
\hline F10-W & $\operatorname{Rec}$ & August 10 & Min till & March 11 & SW & March 11 & $216 \mathrm{~g}$ & August 11 \\
\hline F11-D & Roo & August 10 & Plough & March 11 & SW & March 11 & $50 \mathrm{~g}$ & August 11 \\
\hline F12-D & Roo & July 10 & Plough & February 11 & SW & February 11 & $216 \mathrm{~g}$ & August 11 \\
\hline F13-D & Roo & July 10 & Plough & February 11 & SB & February 11 & $216 \mathrm{~g}$ & August 11 \\
\hline F14-D & $\mathrm{KP}$ & August 10 & Min till & March 11 & SB & March 11 & $216 \mathrm{~g}$ & August 11 \\
\hline F15-D & MP & August 10 & Plough & February 11 & SW & February 11 & $216 \mathrm{~g}$ & August 11 \\
\hline F16-D & $\operatorname{Rec}$ & August 10 & Plough & February 11 & SB & February 11 & $50 \mathrm{~g}$ & August 11 \\
\hline F17-D & $\operatorname{Rec}$ & August 10 & Plough & March 11 & SB & March 11 & $50 \mathrm{~g}$ & August 11 \\
\hline
\end{tabular}

soil compaction to each site. All harvesting operations were completed as per standard commercial practise, using a $45 \mathrm{~mm}$ mesh equipped harvester. Irrespective of the harvesting status, all fields were mouldboard ploughed to a depth of $\sim 25 \mathrm{~cm}$ with the exception of F10, F14 and F35 which underwent minimal tillage.

For the first rotational crop post-potato, winter wheat was sown into 8 fields, with the remainder left fallow over the winter period before being sown with spring oats $(n=2)$, spring wheat $(n=16)$ or spring barley $(n=25)$. In an attempt to control potato volunteers among these cereal crops, herbicide applications were made on 45 fields. Although up to three different commercial herbicide brands were used at different rates across the surveyed sites, all contained fluroxypr as the active ingredient and as such the total herbicide load per site was equivalent to one of several concentrations $(50 \mathrm{~g} / \mathrm{L}$, $140 \mathrm{~g} / \mathrm{L}, 172 \mathrm{~g} / \mathrm{L}$ or $216 \mathrm{~g} / \mathrm{L}$ ). Of the remaining 6 fields that were not herbicide treated, it is important to note that the original potato crops in F46 and F47 were treated before harvesting with an antisprouting agent containing $60 \% \mathrm{w} / \mathrm{w}$ maleic hydrazide.

\subsection{Weather patterns}

Meteorological data for the relevant periods and mapped across the country from geographically dispersed weather stations was provided directly by Met Eireann, The Irish Meteorological Service (www.met.ie), who record soil temperatures at a $5 \mathrm{~cm}$ depth. Exceptionally, high rainfall was experienced across the sampled counties of Cork, Dublin, Meath, Louth and Wexford through 2009 and 2010. For example, in the period from June to November for both 2009 and 2010, rainfall averaged $151 \%$ and 104\%, respectively, above the 30 year (1961-1990) average with July, August, November of 2009 and July, September and November the wettest months of 2010. This made it difficult to harvest (as seen in several fields, Tables 1 and 2) through 2009 and again in 2010, which was compounded by the consistently low air (average of $-3.6^{\circ} \mathrm{C}$ ) and soil (average of $-0.5^{\circ} \mathrm{C}$ ) temperatures experienced from November 2009 to March 2010 and similarly from November 2010 to February 2011.

\subsection{Assessing volunteer emergence}

Systematic volunteer surveys were conducted in July 2010 and July 2011 by walking in a 'W' from one side of field to the other, during which 100 quadrats $(1 \mathrm{~m} \times 1 \mathrm{~m})$ were scored per field. This was completed on fields F18-F51 (Table 1) in both 2010 and 2011 with field locations recorded via GPS to ensure the accurate identification of each field for successive surveys.

\subsection{Assessing volunteer fecundity}

To evaluate the number and weight of tubers derived from emerging volunteers, 30 randomly selected volunteers were chosen in 2010 and again in 2011 from 18 (F21, F22, F23, F24, F25, F26, F29, F30, F31, F32, F33, F35, F37, F38, F48, F49, F50, F51) of the 34 fields (access into the remaining 16 fields was not possible). Tubers harvested from each volunteer were bagged and stored in a low humidity environment at $6^{\circ} \mathrm{C}$ for 12 weeks. Once dormancy was broken each tuber lot was incubated at $20^{\circ} \mathrm{C}$ ( $18 \mathrm{~h}$ day length) to maximise the potential for sprouting to occur and thereby allow the rate of tuber viability to be calculated.

\subsection{Quantifying post-harvest tuber loss and follow on volunteer emergence in designated fields}

In 2010, a separate cohort of 17 fields (Table 2) was selected to survey post-harvest tuber loss and to assess its potential impact on subsequent volunteer emergence in the following rotation crop. Field locations were recorded via GPS to ensure the accurate identification of each field for follow up volunteer surveys. Tuber loss was recorded immediately after harvest and before follow on tillage operations and was noted as the number of whole tubers present on the soil surface within a measured area. Using a $1 \mathrm{~m} \times 1 \mathrm{~m}$ quadrat and adopting a systematic survey approach, a total of 100 quadrat measurements were determined across each field by walking in a ' $W$ ' from one side of the field to the other. Tubers that were physically damaged and/or tuber pieces were excluded from the survey and it was not an objective of the study to survey for the deposition of tubers into sub-surface soil layers. Within a week of harvesting five fields (F1, F2, F7, F8 and F9) were ploughed and returned to winter cereal, while the remaining 12 fields remained fallow over the winter of 2010-2011 before being sown with spring barley/wheat. Counts on subsequent volunteer emergence were recorded in July 2011 using the method described previously. Tuber number per volunteer was calculated based on the random selection of $30 \mathrm{vol}-$ unteers per field $(n=17)$. 


\subsection{Data analysis}

Data such as harvest loss, volunteer counts, tuber number and weight were recorded using a data logger and imported into spreadsheet files before statistical analysis was completed using GenStat 12 th edition. From this, summary statistics (mean \pm standard error [SE]) were generated to quantify; volunteers ha ${ }^{-1}$, tuber loss ha ${ }^{-1}$, tubers volunteer ${ }^{-1}$ and tuber weight volunteer ${ }^{-1}$. The association between two observed variables was determined using Spearman's rank correlation coefficient. For the 34 field volunteer survey a general linear model (GLM) analysis was used to examine the impact of seven fixed effects (year, location, potato variety, follow on cereal (spring/winter variety), herbicide, presence/absence of potato harvesting and plough/mintill) on volunteer number $\mathrm{ha}^{-1}$. Follow on interaction analyses considered; year $\times$ location, location $\times$ herbicide, year $\times$ herbicide, location $\times$ potato variety, year $\times$ potato variety and herbicide $\times$ potato variety. As the 18 fields selected to study volunteer fecundity were not randomly chosen from within the 34 field cohort, an independent GLM analysis was completed with the same seven effects included as in the volunteer assessments to gauge the impact on 2 variables (tuber number volunteer $^{-1}$ and weight of tubers volunteer ${ }^{-1}$ ). For the post-harvest datasets, which were compiled from 17 fields, GLM analyses were completed to examine: the impact of location and variety effect on the harvest loss variable; the impact of year, location, potato variety, follow on cereal (spring/winter variety), herbicide, presence/absence of potato harvesting and plough/mintill on the variables volunteers ha ${ }^{-1}$ and tuber number volunteer ${ }^{-1}$.

\section{Results}

\subsection{Volunteer survey}

Output from surveying the cohort of 34 commercial fields in the summer of 2010 recorded an average of 29,163 \pm 5154 volunteers per hectare emerging through the first rotational crop post-potato (Fig. 1). As expected, volunteer populations varied across the fields sampled, with one field (F23) recording an estimated 125,350 \pm 543 volunteers ha ${ }^{-1}$; though volunteer numbers in this field decreased to $3497 \pm 67 \mathrm{ha}^{-1}$ in 2011 . Indeed, the mean number of volunteers present in the second rotational crop across the 34 fields (in 2011) decreased to $3727 \pm 877 \mathrm{ha}^{-1}$. While volunteer persistence into 2011 correlated with 2010 volunteer populations $(r=0.8$, d.f $=32, P<0.001$ ); a coefficient of determination $\sim 40 \%$ highlighted the impact of additional factors in addition to the population size of 1 st generation volunteers in the fields. Of the fixed term effects examined (Table 3 a) geographic location strongly influenced $(P<0.001)$ the propensity for volunteers to reoccur over time (location $\times$ year, $P<0.001$ ), irrespective of the potato variety that was originally sown (location $\times$ potato variety, $P=0.246$ ). The 9 fields in Wexford recorded the lowest mean volunteer numbers $\left(2608 \pm 600 \mathrm{ha}^{-1}\right)$, followed by Cork, Meath, Louth and Dublin for 2010. One year later saw a mean $89.4 \%$ decrease in volunteers for the Wexford fields, $86.2 \%$ for Cork, $91.7 \%$ for Louth, $76.6 \%$ for Meath and 88.6\% in Dublin. Three fields (F21, F22 and F23; located in Dublin) recorded the highest number of volunteers in 2010 (Fig. 1). In spite of the absence of a volunteer control programme in the post-potato spring cereal crop for all three fields (which were subsequently sown with parsnips as the second rotation crop post-potato), volunteer populations in the same fields decreased by $96.1 \% 92.6 \%$ and $97 \%$, respectively, in 2011 .

As to be expected, the application of herbicide impacted significantly on volunteer numbers $(P=0.037)$ with increased herbicide concentration decreasing volunteers $h^{-1}(r=-0.5413$, d.f $=32$, $P<0.001)$ and the interaction of herbicide with location $(P=0.015)$ over time $(P<0.001)$ further reducing volunteer numbers. For two fields (F46 and F47, located in Wexford), the application of a sprout suppressant (active ingredient maleic hydrazide) prior to potato harvesting eliminated volunteer emergence, with repeated surveys in the subsequent spring barley and winter wheat crops of 2010 and 2011, respectively, confirming the total absence of viable potato volunteers from both fields (Fig. 1).

Selection of the potato variety sown was found to exert a nominally significant effect $(P=0.045)$ with the least number of volunteers recorded on fields with var. Maris Piper $(10,035 \pm 4105$, $n=5$ ), compared to fields previously sown with var. Rooster $(32,576 \pm 6916, n=22)$ and var. Kerr's Pink $(32,100 \pm 11,169$, $n=7)$ : the ranking remained the same with an adjusted value $(16,724 \pm 432, n=3)$ for var. Maris Piper with respect to omitting fields W8 and W9; from which volunteers were eliminated with the use of the anti-sprouting agent.

Arising from the excessively wet and cold weather in the winter of 2009 harvesting operations were not completed in 5 fields, from which it was expected a substantially higher number of volunteer $\mathrm{ha}^{-1}$ would occur in 2010 . However, the full/or partial removal of the potato crop from the fields did not appear to impact significantly on volunteer number $(P=0.274)$ with in fact the average volunteer ha ${ }^{-1}$ of each field lower that the sampled average across the 34 fields combined. Likewise, the occurrence of volunteers was not significantly affected by whether the grower included a spring or winter cereal in the rotation after potato $(P=0.917)$ or indeed whether the $1 \mathrm{st}$ tillage operation after potato was plough-based or minimal tillage; although the latter is likely to be strongly influenced by the unbalanced number of ploughed fields $(n=32)$ versus those that underwent minimal tillage $(n=2)$ in the survey.

\subsection{Volunteer fecundity}

In 2010 , a mean of $2.9 \pm 0.2$ tubers volunteer $^{-1}$ was produced with a maximal of $4.4 \pm 0.4$ (field F50) and a minimal of $0.43 \pm 0.13$ (field F21 across the 18 fields sampled (Fig. 2A). The combined interaction of herbicide and time impacted significantly $(P<0.001$, Table $3 \mathrm{~b}$ ) reducing mean tuber yield volunteer ${ }^{-1}$ by $46 \%$ with F23 yielding a maximum of $2.76 \pm 0.25$ tubers and F34 recording $0.04 \pm 0.03$ tubers volunteer ${ }^{-1}$. The variety of potato sown did not influence tubers volunteer ${ }^{-1}$ in the studied fields $(P=0.679)$. Of interest, was the data recorded from F21, F22 and F23, which reported the highest number of volunteers ha ${ }^{-1}$ in 2010 (Fig. 1) and which were the only fields where parsnips were cultivated in the rotation after potatoes. In contrast to a decreasing trend for all of the other fields sampled, between 2010 and 2011 average tuber number volunteer ${ }^{-1}$ in F21 and F23 increased $84.9 \%$ and $34.7 \%$, respectively. In the case of F22, the average yield per volunteer decreased by just $8 \%$ from 2010 to 2011 .

The average weight of tubers volunteer ${ }^{-1}$ harvested in 2010 was $151.62 \mathrm{~g} \pm 19.97 \mathrm{~g}$ but decreased significantly $(P<0.001$, Table $3 \mathrm{~b})$ by $68.6 \%(47.50 \mathrm{~g} \pm 10.53 \mathrm{~g}$ ) for the 2011 volunteer population (Fig. 2b). Of significance, the viability of all volunteer-derived tubers harvested in 2010 and 2011 was confirmed when all stored tubers sprouted under glasshouse conditions following the 12 week dormancy breaking cold treatment (data not shown).

\subsection{Degree and impact of post-harvest tuber loss}

Across the 17 fields surveyed in the autumn of 2010 mean tuber loss equated to $141,758 \pm 911 \mathrm{ha}^{-1}$ (Table 4), with the highest and lowest degree of tuber loss recorded in F1 $(210,513 \pm 973)$ and F13 $(39,082 \pm 669)$, respectively. Neither field location $(P=0.411)$ nor potato variety harvested $(P=0.233)$ had a significant impact on the rate of tuber loss. Revisiting the field in summer 2011, the number of volunteers present ranged from $400 \pm 59 \mathrm{ha}^{-1}$ (F1) to 


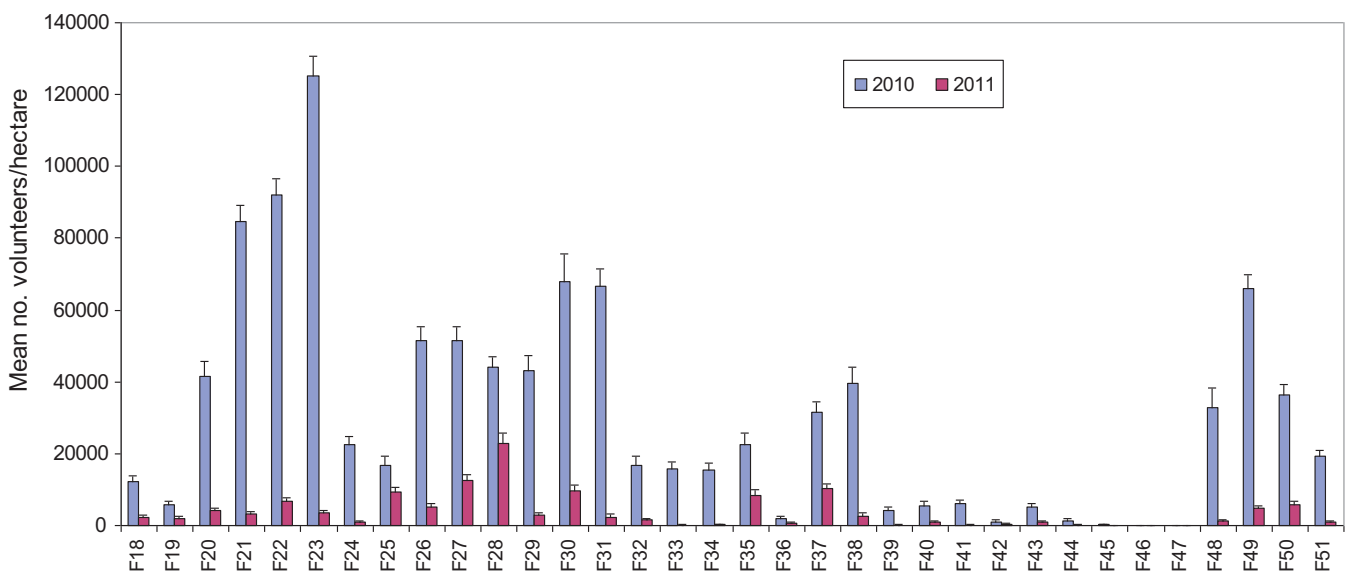

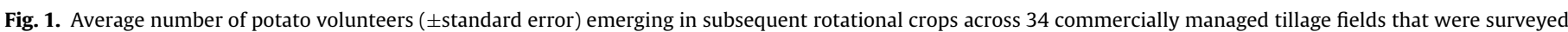
in the first (2010) and second year (2011) after potato crop cultivation in 2009.

Table 3

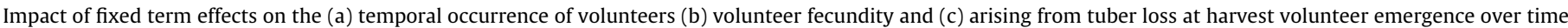
based on completion of general linear model statistical analyses of collated data (see Section 2.6 for methodology and description).

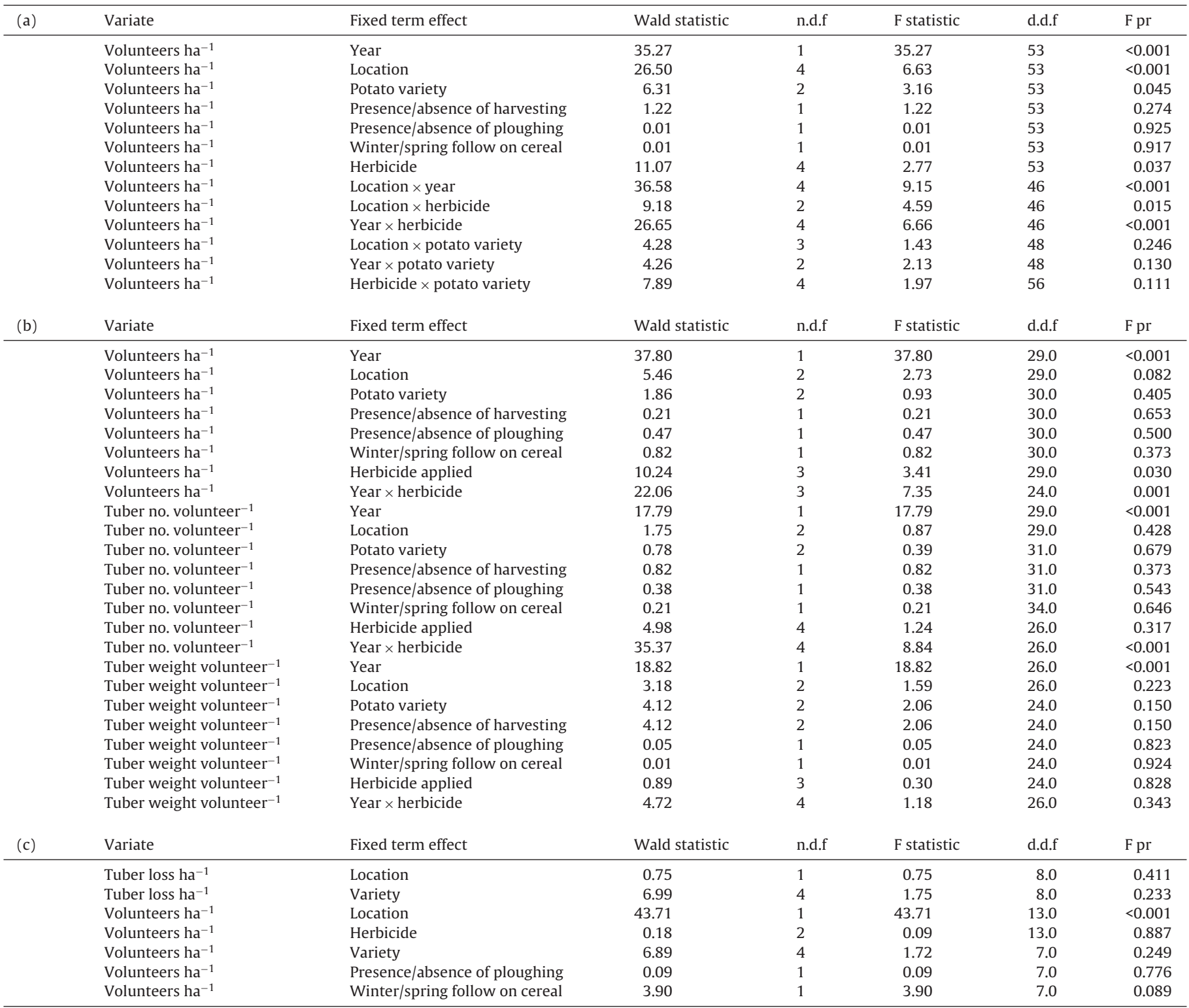



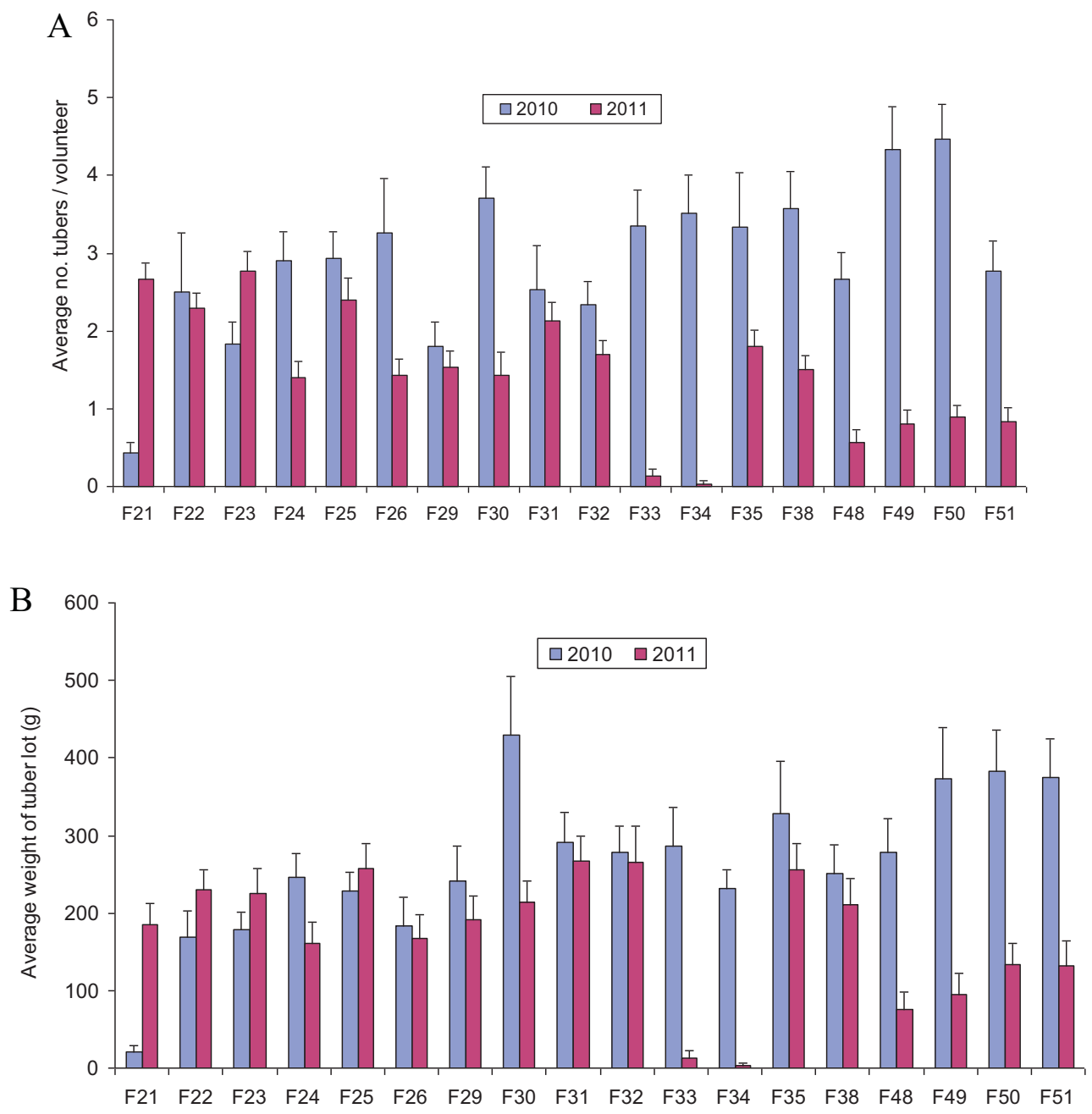

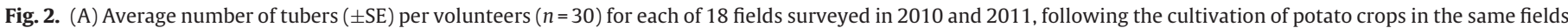

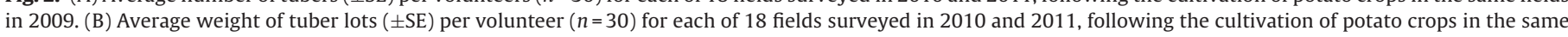
fields in 2009.

$55,698 \pm 47 \mathrm{ha}^{-1}$ (F12) but no definitive association was identified between tubers lost onto the soil surface behind the harvester and subsequent volunteer emergence the following year $(r=-0.237$, d.f $=15, P=0.089)$. As with the previous volunteer survey, field location had a significant effect $(P<0.001$, Table 3$)$ on volun- teers ha ${ }^{-1}$, as noted between the southeastern fields $(n=10)$ of Wexford ( $1627 \pm 328$ volunteers ha $\left.{ }^{-1}\right)$ compared to the more northerly fields of Dublin $\left(n=7,35,876 \pm 3769\right.$ volunteers ha $\left.{ }^{-1}\right)$. However, this was not the case for the application of herbicide $(P=0.887)$; nor for the presence/absence of ploughing as 1 st tillage

Table 4

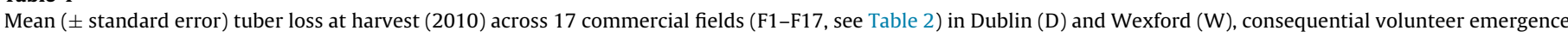
in the rotational crop of 2011 for each field and average number of tubers harvested per volunteer $(n=30)$ sampled from each respective field.

\begin{tabular}{|c|c|c|c|c|c|}
\hline Field code & Potato variety & Harvest loss (tubers per hectare) & Rotational crop & Volunteers (per hectare) & Tuber number per volunteer \\
\hline F1-W & Rooster & $210513 \pm 973$ & Winter wheat & $400 \pm 59$ & $0.16 \pm 0.004$ \\
\hline F2-W & Rooster & $78066 \pm 948$ & Winter wheat & $1899 \pm 64$ & $0.84 \pm 0.01$ \\
\hline F3-W & Kerr's Pink & $119649 \pm 723$ & Spring wheat & $1899 \pm 29$ & $0.88 \pm 0.01$ \\
\hline F4-W & Kerr's Pink & $172228 \pm 553$ & Spring wheat & $2998 \pm 29$ & $1.39 \pm 0.01$ \\
\hline F5-W & Maris Piper & $135842 \pm 568$ & Spring barley & $2499 \pm 27$ & $0.28 \pm 0.001$ \\
\hline F6-W & Maris Piper & $161933 \pm 1328$ & Spring barley & $3299 \pm 27$ & $0.49 \pm 0.002$ \\
\hline F7-W & British Queen & $174527 \pm 775$ & Winter wheat & $797 \pm 5$ & $0.15 \pm 0.002$ \\
\hline F8-W & British Queen & $133244 \pm 555$ & Winter wheat & $798 \pm 42$ & $0.13 \pm 0.002$ \\
\hline F9-W & British Queen & $154836 \pm 1158$ & Winter wheat & $699 \pm 20$ & $0.19 \pm 0.003$ \\
\hline F10-W & Records & $149938 \pm 1536$ & Spring wheat & $1000 \pm 37$ & $0.26 \pm 0.003$ \\
\hline F11-D & Rooster & $81265 \pm 1156$ & Spring wheat & $30198 \pm 72$ & $24.75 \pm 0.05$ \\
\hline F12-D & Rooster & $89663 \pm 1079$ & Spring wheat & $55698 \pm 47$ & $16.80 \pm 0.03$ \\
\hline F13-D & Rooster & $39082 \pm 669$ & Spring barley & $49130 \pm 27$ & $10.27 \pm 0.06$ \\
\hline F14-D & Kerr's Pink & $191121 \pm 462$ & Spring barley & $35578 \pm 15$ & $3.02 \pm 0.04$ \\
\hline F15-D & Maris Piper & $159734 \pm 1632$ & Spring wheat & $27298 \pm 27$ & $4.72 \pm 0.02$ \\
\hline F16-D & Records & $201616 \pm 736$ & Spring barley & $28298 \pm 42$ & $8.07 \pm 0.03$ \\
\hline F17-D & Records & $156635 \pm 645$ & Spring barley & $24929 \pm 52$ & $12.05 \pm 0.05$ \\
\hline
\end{tabular}


operation $(P=0.776)$, potato variety sown $(P=0.249)$ or whether a spring/winter cereal followed the potato crop $(P=0.089)$. As expected a strong linear relationship was identified between volunteers ha ${ }^{-1}$ and number of tubers volunteer ${ }^{-1}(r=0.894$, d. $f=15$, $P<0.001)$.

\section{Discussion}

The initial goal of this study was to catalogue the degree of volunteer emergence and subsequent volunteer fecundity in follow on cereal crops after the cultivation of a potato crop. Arising from the preliminary findings from that survey, an additional investigation was undertaken to (i) gauge the level of tuber loss in commercial potato farms and then (ii) monitor the resulting volunteer emergence related to such tuber loss. Substantial anecdotal evidence (from Irish crop reports) exists to suggest tuber loss at harvest could be significant; nevertheless, the degree of post-harvest tuber loss recorded here was surprising. Based on national statistics (www.cso.ie), a hectare of potatoes will typically deliver a harvestable yield of $\sim 40 \mathrm{tha}^{-1}$ ( $\sim 10500$ tubers $\mathrm{t}^{-1}$, variety dependent). While the imposition of an economic loss related to the phenomenon of tuber loss recorded in this study is not possible since the lost tubers did not meet the size criteria required for market, this level of tuber loss presents a significant weed management issue in subsequent rotational crops due to the emergence of potato volunteers.

A perennial weed, volunteer potato plants are considered a major agronomic problem in crop rotations (Boydston and Williams, 2005; Williams and Boydston, 2006, 2002; Nieuwenhuizen et al., 2010) due in part to their ability to withstand control measures (Koepke-Hill et al., 2010). Previous reports have noted that volunteers are minimally affected by several herbicides applied in UK rotations (Turley, 2001). In contrast, applications of dicamba, 2,4-D, or fluroxypr can significantly reduce volunteer numbers in follow on maize crops (Boydston, 2001). Equivalent to this study, fluroxypr applications were found to significantly reduce the number of potato volunteers in follow on crops, based on the observations made in the 34 field survey. In contrast to (Boydston, 2001) who reported volunteer potato tuber weight reductions of up to $96 \%$ with the use of herbicides, in the 18 fields surveyed here the observed $>65 \%$ reduction in tuber weight between 2010 and 2011 was not found to be related to herbicide usage across the fields. More surprising was the fact that the influence of herbicide was not as evident across the separate 17 field survey as it was in the larger 34 field survey. Considering multiple factors (e.g. machinery performance, timing of application relative to volunteer growth stage, appropriate chemical mix preparation, environmental conditions at time of application) underpin herbicide efficacy, it is clear from this study that further research is required to identify the most appropriate treatment and associated application parameters to ensure growers maximise returns from current herbicide strategies. In contrast, the application of a sprout suppressant prior to the harvesting of potato crops proved a very effective mode of volunteer control, with the suppressant eliminating volunteer emergence through two succeeding rotational crops (as confirmed by multiple site visits). Undoubtedly effective as a method to control volunteers, its application in any coexistence strategy to prevent the emergence of GM volunteers in rotations would have to be considered based on whether the GM potato crop was grown for seed multiplication or not.

The strongest impediment to the proliferation of volunteers was noted to be time and location. Across all the variables examined, a year-on-year reduction was observed indicating the importance of maintaining rotations in cropping regimes. The effect of location is most probably due to the variable soil types between the counties included in the survey and the fact that the south eastern and southerly counties are typically based on finer soils. Therefore, tubers lost at harvest and which are ploughed into the sub-soil are possibly more vulnerable to climate effects than in the heavier and more insulated soils of Dublin, Louth and Meath.

Based on the weather temperatures and precipitation recorded during the survey a high mortality rate was assumed based on previous reports (Lutman, 1977) which noted up to $50,000 \mathrm{ha}^{-1}$ volunteers emerging in winter wheat crops. This corresponds to the numbers recorded in this study, which while high can be predicted to only increase as winters become milder in line with climate prediction models (McElwain and Sweeney, 2007). The fact that potato variety, follow on cereal type, and plough/min-till had no discernible influence on volunteer number implies the problem is ubiquitous and that solutions must therefore focus on mitigating tuber loss at harvest.

On that subject, the lack of any significant association between tuber loss ha ${ }^{-1}$ and variety sown (or location planted) indicates attention must focus on the harvesting process itself. For all the fields examined, harvesting and grading was completed in situ, with grading and stone removal completed by workers positioned on a platform at the rear of the harvester. This operation reduces processing costs for the grower and ensures harvested potato lots are free of stones and other debris. The operation also leads to substantial amounts of tuber loss as tuber pieces and tubers below the marketable diameter are discarded back on to the soil surface behind the harvester. While this study only considered whole tubers visible on the soil surface, it has to be assumed that the total amount of tuber material (which can result in viable volunteers) is in fact higher as tuber and/or tuber pieces could also be covered by soil debris during harvesting and hence not be visible for scoring and assessment. Quite simply, reducing the levels of harvest lost recorded here would require either (i) a re-engineering of the harvester to include an additional mechanism to collect tube pieces/unsaleable tubers or (ii) a reversal of current practises that would see all harvested material removed from the field for processing and grading. As both options have cost implications for the grower, any motivation to pursue either option will only occur in the presence of a financial benefit and/or due to a regulatory decree.

The volunteer numbers recorded in this study identify a genuine challenge for regional disease control; as potato volunteers can be regarded as primary sources of late blight inoculum (Cooke et al., 2011). Considering the impact of late blight disease on the Irish potato crop (Dowley et al., 2008), the potential for volunteers to act as a vector for late blight disease into neighbouring crops is real and at a minimum is likely to contribute to the perpetuation of late blight epidemics; this while growers adopt 15 spray programmes to exert control over the disease in adjacent potato crops.

Overall, managing gene flow (be it pollen- or seed-mediated) is a critical step if effective coexistence strategies are to be implemented and sustained. The imposition of separation distances between GM and related non-GM crops is an accepted measure to offset the challenge pollen-mediated gene flow poses to coexistence (ACRE, 2004; Eastham and Sweet, 2002; McGill et al., 2005; Tolstrup et al., 2003). Owing to the clonal propagation of potato, pollen transfer across potato crops will not impact on the genetic integrity of tubers harvested from receptor plants. In contrast, seed-mediated gene flow via tuber loss presents a greater challenge to the effective management of any future GM potato crops (Flannery et al., 2005). The findings of this study, combined with a previous report (Turley, 2001) and grower's experiences, confirm that the absence of an effective volunteer control strategy will thwart the imposition of efficient coexistence should it be required.

Based on National potato production figures from 2007 to 2010, the mean number of tubers harvested per hectare is 339,533 
( $\pm 30,721)$. Imposing the standard $0.9 \%$ coexistence threshold would imply that the number of volunteer-derived tubers should not exceed $3058 \mathrm{ha}^{-1}$. While this study did not go beyond examining the fecundity of 2 nd generation volunteer-derived tubers, it is important to note that a previous report (McGill et al., 2005) recommended a minimum 4 year rotation be applied before a conventional potato crop could be re-sown into a field that was previously used for GM potato cultivation. Based on what has been identified in this research, it is likely that the $0.9 \%$ limit would be compromised unless robust volunteer controls are in situ and/or the rotation is in fact extended beyond the recommended 4 years.

In this study, we only recorded harvest loss in a single year (2010) and did not examine the deposition of tubers below the soil surface. Nevertheless, the presented data clearly confirms the propensity for seed-mediated gene flow from commercial potato crops and that volunteer-derived tubers are of adequate number and weight to maintain subsequent volunteer populations. Whereas the goal of coexistence is to facilitate choice for the grower in affording them the option to choose between GM, conventional or organic, there must also be a guarantee that the genetic integrity of equivalent non-GM crops is maintained. For any future GM potato cultivation, volunteer management will be key to ensuring that this is achieved.

\section{Acknowledgement}

This work was supported through the Department of Agriculture, Fisheries, Food and the Marine's Research Stimulus Fund (RSF 07352). The authors are grateful to the potato growers for their time and for providing access to their land, for the technical assistance provided by John Paul Fenlon, Alan Hendy and Eamon Shiels during the manual harvesting of tubers, expert reviews of the manuscript provided by Michael Hennessy and Denis Griffin and weather data provided by Met Eireann.

\section{References}

ACRE, 2004. Advice on scientific issues concerning the proposed regime for the co-existence of GM and non-GM crops, in, Advisory Committee on Releases to the Environment, Department for Environment, Food and Rural Affairs, pp. 6.

Boydston, R.A., Williams, M.M., 2005. Managing Volunteer Potato (Solanum tuberosum) in field corn with Mesotrione and arthropod herbivory. Weed Technol. 19, 443-450.

Boydston, R.A., 2001. Volunteer Potato (Solanum tuberosum) control with herbicides and cultivation in field corn (Zea mays) 1 . Weed Technol. 15, 461-466.

Cooke, L.R., Schepers, H.T.A.M., Hermansen, A., Bain, R.A., Bradshaw, N.J., Ritchie, F. Shaw, D.S., Evenhuis, A., Kessel, G.J.T., Wander, J.G.N., Andersson, B., Hansen, J.G., Hannukkala, A., Naerstad, R., Nielsen, B.J., 2011. Epidemiology and integrated control of potato late blight in Europe. Potato Res. 54, 183-222.

Dowley, L.J., Grant, J., Griffin, D., 2008. Yield losses caused by late blight (Phytophthora infestans (Mont.) de Bary) in potato crops in Ireland. Irish J. Agric. Food Res. 47, 69-78.

E. Commission, 2003. Commission recommendation of 23 July 2003 on guidelines for the development of national strategies and best practices to ensure the co-existence of genetically modified crops with conventional and organic farming, Brussels Commission of the European Communities.

Eastham, K., Sweet, J., 2002. Genetically Modified Organisms (gmos): The Significance of Gene Flow Through Pollen Transfer. European Environment Agency, Copenhagen, pp. 1-75.

Flannery, M.L., Meade, C.V., Mullins, E., 2005. Employing a composite gene-flow index to numerically quantify a crop's potential for gene flow: an Irish perspective. Environ. Biosaf. Res. 4, 29-43.
Fry, W.E., 2008. Phytophthora infestans: the plant (and R gene) destroyer Phytophthora infestans: the plant (and R gene) destroyer. Mol. Plant Pathol. 9, 385-402.

Haverkort, A.J., Boonekamp, P.M., Hutten, R., Jacobsen, E., Lotz, L.A.P., Kessel, G.J.T., Visser, R., van Der Vossen, E., 2008. Societal costs of late blight in potato and prospects of durable resistance through cisgenic modification. Potato Res. 51, 47-57.

Haverkort, A.J., Struik, P.C., Visser, R.G.F., Jacobsen, E., 2009. Applied Biotechnology to Combat Late Blight in Potato Caused by Phytophthora Infestans. Potato Res. 52, 249-264.

Jones, J.D.G., Witek, K., Verweij, W., Jupe, F., Cooke, D., Dorling, S., Tomlinson, L., Smoker, M., Perkins, S., Foster, S., 2014. Elevating crop disease resistance with cloned genes. Philos. Trans. R. Soc. B: Biol. Sci. 369.

Koepke-Hill, R.M., Armel, G.R., Wilson, H.P., Hines, T.E., Vargas, J.J., 2010. Herbicide combinations for control of volunteer potato. Weed Technol. 24, 91-94.

Lumkes, L.M., 1974. Research on the control of volunteer potatoes in The Netherlands. Proc. Br. Weed Control Conf., 1031-1040.

Lutman, P.J.W., 1977. Investigations into some aspects of the biology of potatoes as weeds. Weed Res. 17, 123-132.

McDonald, B.A., Linde, C., 2002. The population genetics of plant pathogens and breeding strategies for durable resistance. Euphytica 124, 163-180.

McElwain, L., Sweeney, J., 2007. Key Meteorological Indicators of Climate Change in Ireland. Environmental Research Centre - ERC Rerport 6, Environmental Protection Agency.

McGill, G., O'Reilly, C., Thorp, K., Armstrong, S., Gaule, F., Macken, J., Downey, J. Dardis, R., Devlin, B., Leech, T., Mullins, E., 2005. Coexistence of GM and non-GM Crops in Ireland. Report of the Working Group on the Coexistence of GM crops with Conventional and Organic Farming. Department of Agriculture and Food, Dublin, pp. 286.

Nieuwenhuizen, A., Hofstee, J., Henten, E., 2010. Adaptive detection of volunteer potato plants in sugar beet fields. Precis. Agri. 11, 433-447.

Perminow, J.I.S., Akselsen, I.L.W., Borowski, E., Ruden, Ø., Grønås, W., 2012. Potato ring rot in Norway: occurrence and control. Potato Res. 55, 241-247.

Petti, C., Meade, C., Downes, M., Mullins, E., 2007. Facilitating co-existence by tracking gene dispersal in conventional potato systems with microsatellite markers. Environ. Biosaf. Res. 18.

Song, J., Bradeen, J.M., Naess, S.K., Raash, J.A., Wielgus, S.M., Haberlach, G.T., Liu, J., Kuang, H., Austin-Phillips, S., Buell, C.R., Helgeson, J.P., Jiang, J., 2003. Gene RB cloned from Solanum bulbocastanum confers broad spectrum resistance to potato late blight. Proc. Natl. Acad. Sci. U. S. A. 100, 9128-9133.

Toevs, E.A., Guenthner, J.F., Johnson, A.J., McIntosh, C.S., Thornton, M.K., 2011. Identify preservation systems for genetically modified potatoes. Am. J. Potato Res. 88, 303-308.

Tolstrup, S.B., Andersen, B., Boelt, M., Buus, M., Gylling, P.B., Holm, G., Kjellsson, S., Pedersen, H., 2003. Report from the Danish Working Group on the Co-existence of genetically modifed crops with conventional and organic crops. DIAS Report Plant Production No. 94, pp. 275.

Turley, D., 2001. Understanding the Biology and Incidence of Potato Volunteers. British Potato Council, Oxford.

Van Der Vossen, E., Sikkema, A., te Lintel Hekkert, B., Gros, J., Stevens, P., Muskens, M., Wouters, D., Pereira, A., Stiekema, W., Allefs, S., 2003. An ancient R gene from the wild potato species Solanum bulbocastanum confers broad-spectrum resistance to Phytophthora infestans in cultivated potato and tomato. Plant J. $36,867-882$

Vleeshouwers, V.G.A.A., Raffaele, S., Vossen, J.H., Champouret, N., Oliva, R., Segretin, M.E., Rietman, H., Cano, L.M., Lokossou, A., Kessel, G., Pel, M.A., Kamoun, S., 2011. Understanding and exploiting late blight resistance in the age of effectors. Annu. Rev. Phytopathol. 49, 507-531.

Williams, M.M., Boydston, R.A., 2002. Effect of shoot removal during tuberization on volunteer potato (Solanum Tuberosum) tuber production. Weed Technol. $16,617-619$

Williams, M.M., Boydston, R.A., 2006. Volunteer potato interference in carrot. Weed Sci. 54, 94-99.

Wright, G.C., Bishop, G.W., 1981. Volunteer potatoes as a source of potato leafroll virus and potato virus X. Am. Potato J. 58, 603-609.

Zhu, S., Li, Y., Vossen, J., Visser, R.F., Jacobsen, E., 2012. Functional stacking of three resistance genes against Phytophthora infestans in potato. Trans. Res. 21, 89-99.

van Elsas, J.D., Kastelein, P., van Bekkum, P., van der Wolf, J.M., de Vries, P.M., van Overbeek, L.S., 2000. Survival of ralstonia solanacearum biovar 2 the causative agent of potato brown rot in field and microcosm soils in temperate climates. Phytopathology 90, 1358-1366. 